\title{
Student-centered methods in entrepreneurship education to increase entrepreneurial intentions of students
}

\author{
Inese Mavḷutova, Māris Krastiṇš, Jānis Hermanis, Kristaps Lešinskis
}

BA School of Business and Finance

\begin{abstract}
Nowadays young people and students to prefer paid jobs over setting up of their own businesses. One of the possible ways to increase entrepreneurial intentions is to develop new student-centered entrepreneurship teaching methods. Despite European Commission recognizes that current entrepreneurship education in the EU in general works well and produces positive outcomes in a form of higher probability of starting business, there is a ongoing discussion on necessity to use more student-centered teaching approaches. The aim of the study is to identify the teaching methods to increase entrepreneurial intentions of students. The article addresses theoretical aspects of the role of entrepreneurship education in society, as well methodologies exploited in business education and their features. The core part of the paper contains analysis of survey results conducted among students in higher education institutions in selected European countries from different European parts as well as identification of students-centered teaching methods in entrepreneurship. The research is based on literature analysis, quantitative survey, analysis of statistical data and reports on entrepreneurial activity, new students-centered teaching methods in entrepreneurship education.
\end{abstract}

Keywords: entrepreneurship, entrepreneurial intentions, entrepreneurship education, teaching methods, student-centered learning.

\section{Introduction}

This paper is devoted to constantly important business education issues. With the emergence of digitalization and artificial intelligence, higher education institutions are seeking for new approaches to more modern business studies and revising the old ones.

In recent years, trends have emerged that are unfavorable for higher education institutions offering entrepreneurship training. Given the scarcity of studies carried out outside of the business school, a number of scholars have called for a new approach to entrepreneurship education (Syed, Abdul and Norita, 2018)

Another problem is that business study courses lack student orientation and practical side of the learning, especially in non-business education institutions (e.g. engineering courses 
or vocational education institutions or even secondary schools). If these type of educational institutions deliver business study courses, they are mostly theoretical with lack of practical approach.

The importance of how entrepreneurship education should be taught or the appropriate teaching method is still a fundamental issue in entrepreneurship education (Syed, Abdul and Norita, 2018) that is part of an ongoing scholarly debate. Teaching contents and methods would be the decisive factors of success for teaching entrepreneurship in the twenty-first century. Unfortunately, very little is known about effective teaching techniques for entrepreneurship (Deale, 2016) and research and knowledge about how to teach entrepreneurship remains relatively underdeveloped despite the growing demand for more entrepreneurial-oriented graduates (Chief Scientist, 2019). Having recognized this gap, this paper aims to critically review and evaluate the main teaching methods of entrepreneurship and discusses the effectiveness of the specific teaching methods in entrepreneurship education.

This paper tries to determine the relevance of the teaching methods effectiveness in the entrepreneurship education specifically. However, this article is not intended to be a compendium that provides all the possible techniques on how to teach entrepreneurship but is rather an analysis of the widely used teaching pedagogy applied in the entrepreneurship education. The first step was to perform an evaluation or assessment of the past and present teaching methods of entrepreneurship education in terms of their strengths and limitations. While there exist many different definitions of teaching methods or practices, we define teaching method as the general principles, pedagogy and strategies used in teaching. One of the greatest challenges for educators is determining the effectiveness of teaching methods for students (Syed, Abdul and Norita, 2018)

Despite the shortcomings of the traditional teaching methods and overwhelming number of studies suggesting teaching of entrepreneurship using "innovative" methods (Hooshangi, Arasti, Hounshell and Sahebzamani, 2012) (Deale, 2016), lectures, case studies and group discussions continue to be the most commonly used pedagogies in many universities worldwide (Syed, Abdul, \& Norita, 2018).

\section{Methods and Data}

\section{Entrepreneurship literature analysis}

The term entrepreneurship is always revolving and varies across different industries and fields, making it difficult for people to define it. For example, Jones (Jones, English, 2004) define entrepreneurship as "the process of providing individuals with the ability to recognize commercial opportunities and the insight, self-esteem, knowledge and skills to act on them". Varley and Hardy (Varley, Hardy and Sewell, 2010), on the other hand, define entrepreneurship as "the desire, motivation and skills necessary to start and manage a successful business". 
Joseph Schumpeter (1943), Frank Knight (1921) and Israel Kirzner (1973) investigated phenomena of entrepreneurship. Schumpeter suggested that entrepreneurs, not just companies, are responsible for the creation of new things in the search of profit. Knight focused on entrepreneurs as the bearers of uncertainty and believed they were responsible for risk premiums in financial markets and Kirzner thought of entrepreneurship as a process that leads to discovery. A summary of these ideas is available in a study conducted by Krumina (Krumina, 2017).

The authors believe entrepreneur is an individual who starts and runs a business with limited resources and planning, and is responsible for all the risks and rewards of his or her business venture.

Entrepreneurship is one of the main actors in national economy for any country (Salinas and Barroso, 2016). For Ahmad and Seymour (2008), there are some common elements that impulse people for entrepreneurship, such as the capacity for finding and exploiting a business opportunity, intention to understand the entrepreneur's behaviour.

Feldman, Bolino (2010), as well as Katz (2004), believe that the intention to become an entrepreneur depends on the individual's will because people value the possible results, economic impact and community benefits. This could be based on the environment, sociodemographic and perception features.

Drucker (2002) comments that successful entrepreneurs don't wait for new and creative ideas to come. Would-be innovators and entrepreneurs must go out of the firm, look, ask and listen, in a process for exploring discovering-learning process. Family, personal economy and academic level also have influence in the process of entrepreneurship (Barroso, 2012; Salinas, 2014). Quijano (2006) argues that productivity is affected by factors such as motivation, labour satisfaction, learning, academic level, work habits, labour environment, attitudes, feelings, decision making, conflict solution, ergonomics, management style, organizational culture.

When entrepreneurship is treated as the ability to generate and implement novel ideas within a business context. Creativity can therefore be seen as an important antecedent of entrepreneurial intentions and consequently individuals with a well-trained creative skillset are more likely to engage in entrepreneurship (Ward, 2004).

There are people who think they are not creative, but everybody is. Creativity is inherent to our nature and must be, as Robinson (2006) said, treated at the same level and importance as literacy. It has its own value, as De la Torre (1997) stated, but only when it creates value and becomes innovation (Gupta, 2012), so to be innovative, the first step is fostering creativity. And if there's orientation to innovation, there will be the possibility for individuals to be entrepreneurs. Barroso (2017) believes that the creator has an idea, the inventor makes it work, the innovator gives value to that idea and the entrepreneur takes the risk and takes it to the market, transformed into a product.

The existence of a business idea is a primary determinant entrepreneurial intention in the early stage of a new business creation (Badri, Hachicha, 2019). One of the most 
common ways is to find a business idea in a familiar and close-knit sphere, but one's good hobby, professional skills or any other source of initiative can be just as good.

In most cases students intending to start their own business have an entrepreneurial idea before shaping their project. Evaluating the idea by attracting external expertise especially using digital systems can be a success and can significantly help to improve the idea, but at the same time, one can also give up the idea. New entrepreneurs should always take the external expertise seriously accept the assessment objectively and use several sources of expertise. Forming an entrepreneurial intention requires formulating an idea structured, which would explain the students' entrepreneurial expectations. Detaining an idea constitutes a necessary step in shaping the students' entrepreneurial intentions (Badri, Hachicha, 2019).

To implement the idea, to analyze the adequacy of initial ambitions of a business idea a business plan is drawn up in which entrepreneurs plan their business for a certain period. The business plan must be concrete, thoughtful, reflect the current situation and future perspectives, and highlight the strengths and weaknesses of the business. The business plan allows entrepreneurs to think about the things they will need when they start their business, to understand the strengths of their idea and to make the necessary computations for the viability of the idea. By setting up a business plan, entrepreneurs can define stop points and the nearest directions as a destination. In addition, the business plan will allow to analyses the adequacy of initial ambitions of a business idea.

Each business plan is based on financial plans that reflect the potential viability and potential return on the investment for the prospective investor, as well as providing insight into other financial indicators. The digital financial plan should include cash flow computation, profit/loss statement and balance sheet. Computations allow to avoid unexpected situations and help planning of coming periods. The most important benefit of the computations in digital formatting is the possibility to model different situations, as well as the possibility to evaluate whether the investment in the project is successful or not, compared to alternative investment possibilities.

\section{Entrepreneurship education and its teaching methods}

Under different titles such as entrepreneurship, small business management, entrepreneurial growth, new ventures creation, new ventures management or enterprise development, many undergraduate and postgraduate programs in business management studies offer entrepreneurship education as compulsory subject (Syed, Abdul, and Norita, 2018).

One of the most commonly used foundational objectives of entrepreneurship education is to encourage students to create their own businesses.

Responding to the importance of entrepreneurship as a major driver of economic growth, entrepreneurship education programs have developed globally in an effort to provide national future entrepreneurs with the necessary skills. The business education programs 
are generally considered to be an effective means of promoting student entrepreneurship, curricula are often focused only on the acquisition of knowledge, and developing skills to properly design a business plan and unfortunately often unable to adequately address and stimulate creative thinking. (Sagie, Elizur, 1999).

The challenges that entrepreneurship education faces in the past have shifted from legitimacy issues to quality issues. The debate is no longer whether entrepreneurship can or should be taught but rather how to continuously improve its content and delivery methods to meet the needs of current students and industries (Syed, Abdul, and Norita, 2018).

Audretsch (2014) describes the importance of education for entrepreneurial thinking, behavior and values within society. Universities with more extensive multidisciplinary profiles play a more significant role in the processes leading to the emergence of new businesses and the commercialization of scientific knowledge (Bonaccorsi et al. 2013). According to Badri (Badri and Hachicha, 2019) educational level is also among the noticeable factors to significantly affect the individuals' desire to engage into an entrepreneurship.

The development of new study programs stimulating entrepreneurship, the involvement of students and lecturers in activities such as business-plan competitions, entrepreneurship clubs, and the practical training undertaken in existing startups and other enterprises is very important to make entrepreneurship studies more interactive and practical.

Entrepreneurship program must satisfy modern needs and comply with the current peculiarities of the business-creation process. Entrepreneurship education also depends on demographic factors such as gender, working experience, parental working experience (whether the student comes from a family of entrepreneurs) or environmental factors such as interactive communication between the students or their involvement and participation in other university communities or meetings.

Motivation for creativity opens another dimension in entrepreneurial process, that is, implementation of business idea. Creative young people can be more easily involved in entrepreneurship because they more obviously perceive feasibility of project.

An effective way to stimulate the creativity and entrepreneurial intentions is putting students in a real problem-solving situations. One of the forms of a personal experience is to attend business incubator. For example, 15 incubators in a small country Latvia ensure support to young entrepreneurs and established merchants, providing the necessary environment including software for business start-up and development, consultations, training and events on general business issues, mentor support and grants. There are several business incubators all over the country in universities and business schools to stimulate entrepreneurial intentions and maturity of students in the age of digitalization.

Another innovative and multidisciplinary approach to teaching entrepreneurship is automatic digital system for assessment of business ideas. The system should assess the commercial viability and competitiveness, innovativeness and creativity of business idea, 
analyses the relevant personal characteristics and preconditions of business idea owner, that will be done automatically or semi-automatically.

Maresch and Harms (Maresch, Harms, Kailer, and Wimmer-Wurm, 2016) have shown that entrepreneurship education increases the entrepreneurial intention, therefore authors take a deeper insight in methods exploited in entrepreneurship education.

The current teaching method is argued to be mainly concerned with creating human resources to work for others not to work for oneself, which calls for a new approach in entrepreneurship education (Syed, Abdul and Norita, 2018) (Deale, 2016). Integrating an entrepreneurship module in the business management curriculum will provide students with the essential knowledge and skills to become effective managers with entrepreneurial skills and capabilities.

The entrepreneurial intention has always been affected by several factors derived from the relevant theoretical and empirical analyses. These factors involve, mainly, the relating individual characteristics, socio-cultural background, entrepreneurship education, the existence of a project-undertaking idea, etc. According to Ajzen's model (Leeuw, Valois, Ajzen and Schmidt, 2015) personality traits and demographic elements (gender, age, etc.), are believed to influence intentions in so far as they affect the individuals' beliefs, i.e. their intentions, to initiate a project. Despite researches (Badri, Hachicha, 2019) that emphasize the role of personal characteristics (age, gender and, above all, educational level), are the most determining variables affecting their intention to engage in entrepreneurship, there is teaching methods that could improve students' intention to start up a business.

One of the major issues in entrepreneurship is how the subject should be taught. It demands the formulation of an integrated learning and teaching strategy that aligns intended learning outcomes with the effective selection of pedagogy. Pedagogy or teaching method is of paramount importance in the learning process, involving effective method, competent instructor, lecturer and sufficient teaching facilities. Given there is somehow a consensus among entrepreneurship education scholars that entrepreneurship can be taught, he emphasis now shifted to what should be taught and how it should be taught (Chief Scientist, 2019) (Badri, Hachicha, 2019) (Deale, 2016). However, Rideout and Gray (Rideout, Grey, 2013) argued that even though there has been some progress in entrepreneurship education, the field is still at a very early stage of development (Syed, Abdul, and Norita, 2018).

The studies dealing with the role of the educational system in developing entrepreneurship were suggested by Ulhoi (Ulhoi, 2005) (Badri, Hachicha, 2019). The impact of entrepreneurship teaching and training has become an important focus area for countries that sought to foster their students' entrepreneurial behavior intentions through education. A wide range of entrepreneurial activities and training were developed in higher education institutions. 


\section{Data}

\section{Statistical data analysis}

In order to achieve the objective of the research, authors analyzed statistical data about entrepreneurial intensions collected by survey organized in the beginning of 2019. More specific, the research was about qualities and preconditions one needs most to become a successful entrepreneur, the most problematic factors for doing business, skills students lack or need to improve most to be able to start an entrepreneurship, the most important factors discouraging students to start an entrepreneurship as well as conducted survey among students in European countries.

According to Global Entrepreneurship Monitor Adult Population Survey data, entrepreneurial intensions and early-stage entrepreneurial activity in Europe stands lowest among global geographic regions today (Graph 1).

Graph 1: Entrepreneurial Intentions and Total Entrepreneurial Activity (TEA) Rates among Adults (ages 18-64) in 48 Economies, in Four Geographic Regions

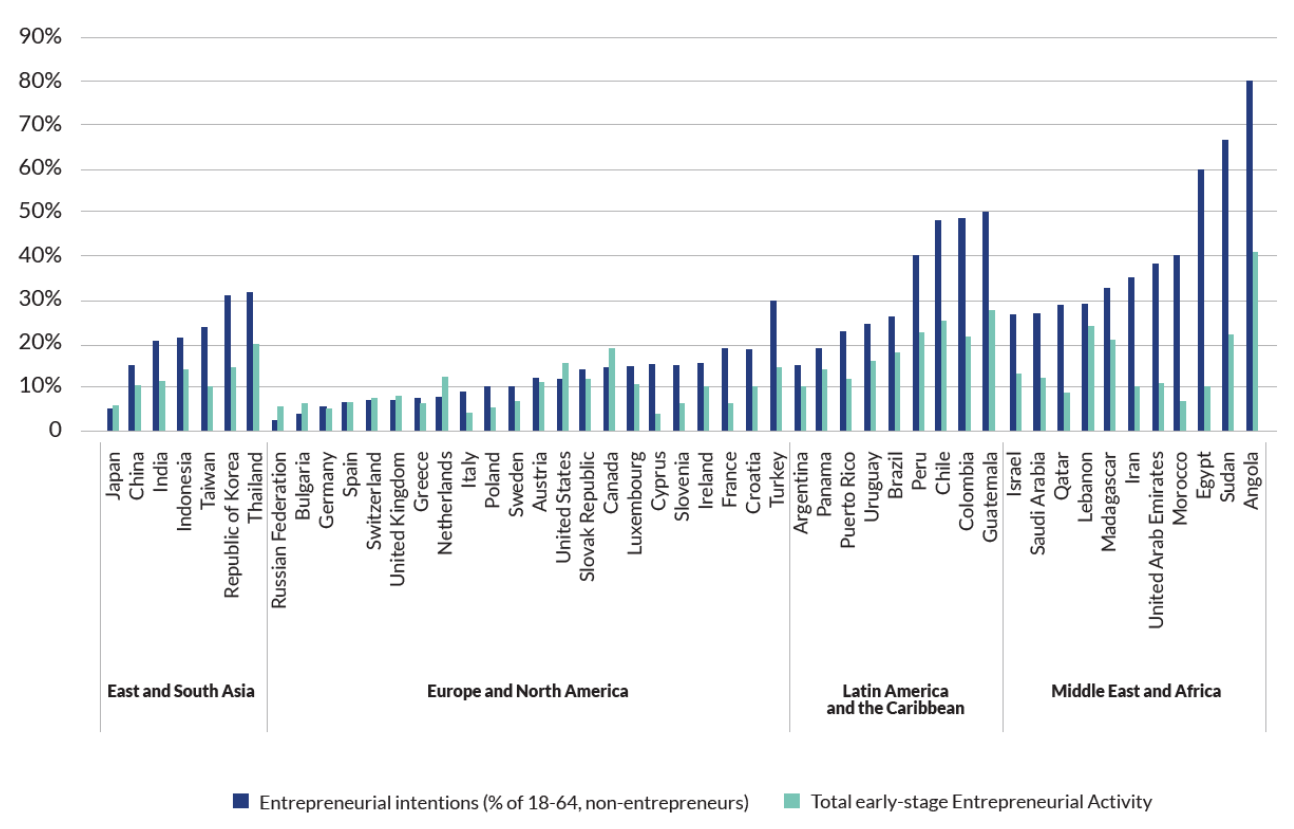

Source: Bosma \& Kelley, 2018.

Entrepreneurial intensions and entrepreneurial activity use to decrease as economic model of the country matures, economy is highly competitive and activities are concentrated in efficient big scale organizations. It partially explains the reasons for low intensions and activity in European countries. At the same time, there is a risk of losing entrepreneurial potential and regeneration of entrepreneurs.

The authors conducted survey among students of European higher education institutions to investigate entrepreneurial intensions, motivation, obstacles and assistance needed. 
The survey was focused on five EU countries - Latvia and Lithuania from Eastern Europe, Belgium from Western Europe, Italy and Portugal from Southern Europe.

Before conducting survey the authors analyzed Global Entrepreneurship Monitor online statistics data (Entrepreneurial behaviour and attitudes, 2019) for the same five countries.

During the analysis the authors found out that entrepreneurial intensions have recently decreased in all selected countries (Graph 2).

Graph 2: Entrepreneurial intensions in selected EU countries, in \% of adult population

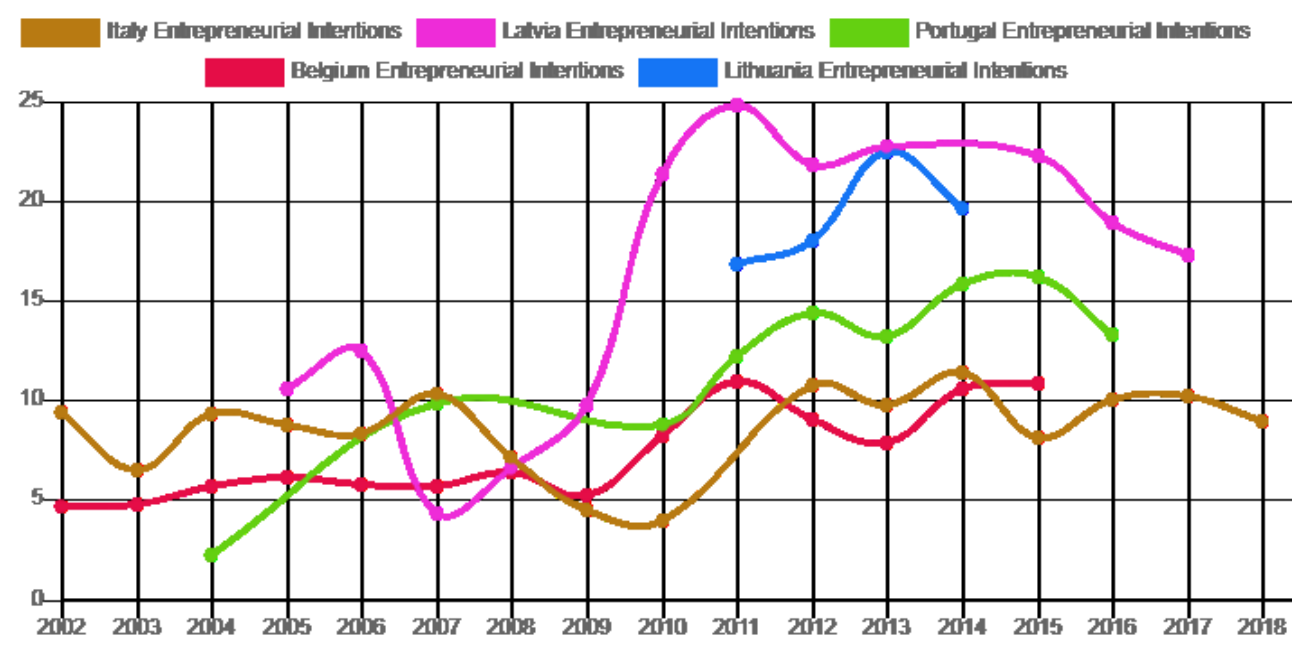

Source: Entrepreneurial behavior and attitudes, 2019.

After the observed increase of entrepreneurial intensions during the global financial crisis and some years after, as labour markets stabilize, unemployment rate decreases and labour market opportunities increase, entrepreneurial intensions start to gradually slow down.

\section{KABADA survey}

In 2018 and the beginning of 2019, the authors developed survey named KABADA to investigate entrepreneurial intensions, motivation, obstacles and assistance needed among European students of higher education. Even though it was spread in many European countries, the focus was on five previously mentioned countries.

The aim of the survey was to analyze students' self-assessment about readiness to start their own business and possession of necessary entrepreneurial skills.

The questionnaire was divided in three sections. In the first section students were asked about their future career plans, in particular, whether they plan to be their own bosses and start their own companies. The second section was devoted to studies of entrepreneurial perceptions, bet the third part investigated students' self-perceptions about their entrepreneurial skills and capabilities.

Number of absorbed respondents in survey is 947. To analyse regional differences, authors made a distinction between old EU members (EU15 or those countries that were 
already EU members until April 30, 2004) and new EU members (EU28 - EU15 or those countries which joined the EU from May 1, 2004 or later).

Most of the respondents were bachelor degree students (86.5\%), the rest being in their master degree studies. The survey was mostly focused on economics, finance and business management programs' students (70.3\% of all students). There were also $10.7 \%$ of respondents majoring in engineering, $6.1 \%$ in natural sciences, mathematics and IT and $4.5 \%$ in education.

Tab. 1 describes respondents' future professional career choices of all respondents. Even though the most popular answer was related to being an employee, $28.6 \%$ of respondents indicated that they see themselves developing and managing their own business which is quite remarkable percentage.

Tab. 1: Professional life intensions of respondents.

\begin{tabular}{|l|r|r|}
\hline In my professional life I see myself: & Numbers & \multicolumn{1}{|c|}{$\%$} \\
\hline developing and managing my own business & 271 & $29 \%$ \\
\hline I have not decided yet & 225 & $24 \%$ \\
\hline working for private or public organization as a specialist or manager & 451 & $48 \%$ \\
\hline & 947 & $100 \%$ \\
\hline
\end{tabular}

Source: KABADA Survey, 2019.

\section{Results}

In KABADA survey, respondents were asked what kind of assistance they would prefer when working on their business ideas (several answers possible). The most popular answers were "finding financial sources" (65.4\%), "checking potential of my business ideas" (59.6\%) and "mentoring and consulting" (52.9\%).

Further, authors decided to check the difference between country groups by detecting weather factor "country group" plays a significant role in distribution of answers to the questions (Fig.1).

Fig. 1: Professional life intensions of respondents by country groups.

\begin{tabular}{|c|c|c|c|c|c|c|c|c|c|c|c|c|c|}
\hline & \multicolumn{4}{|c|}{ EU-15 } & \multirow[t]{2}{*}{ Total } & \multirow[t]{2}{*}{$\%$} & \multicolumn{3}{|c|}{ EU-28 } & \multirow[t]{2}{*}{ Total } & \multirow[t]{2}{*}{$\%$} & \multirow[t]{2}{*}{$\begin{array}{l}\text { Grand } \\
\text { Total }\end{array}$} & \multirow[b]{2}{*}{$\%$} \\
\hline & $B E$ & IT & PT & Others & & & LT & LVV & Others & & & & \\
\hline $\begin{array}{l}\text { developing and managing my } \\
\text { own business }\end{array}$ & 25 & 12 & 19 & 3 & 59 & $24 \%$ & 76 & 112 & 24 & 212 & $30 \%$ & 271 & $29 \%$ \\
\hline I have not decided yet & 14 & 42 & 13 & 1 & 70 & $29 \%$ & 55 & 89 & 11 & 155 & $22 \%$ & 225 & $24 \%$ \\
\hline $\begin{array}{l}\text { working for private or public } \\
\text { organization as a specialist or } \\
\text { manager }\end{array}$ & 20 & 50 & 34 & 12 & 116 & $47 \%$ & 146 & 159 & 30 & 335 & $48 \%$ & 451 & $48 \%$ \\
\hline Grand Total & 59 & 104 & 66 & 16 & 245 & $100 \%$ & 277 & 360 & 65 & 702 & $100 \%$ & 947 & $100 \%$ \\
\hline
\end{tabular}

Source: KABADA Survey, 2019. 
The following hypotheses were tested:

$\mathrm{HO}$ - there is no significant difference in answers' distribution by country groups

$\mathrm{H} 1$ - there is significant difference in answers' distribution by country groups

To test which hypothesis is true, a chi-squared test was run in each case. All tests and following calculations was executed with JASP software - JASP Team (2018), JASP (Version 0.9.2) [Computer software] and the received p-value was checked, where, if pvalue $>0.05$, then $\mathrm{H} 0$ is true, otherwise $\mathrm{H} 1$ is true.

In the case of preferred assistance, $\mathrm{H} 0$ was true for all types of possible assistance with an exception for answer "checking potential of my business ideas" (p-value 0.016), where H1 turned out to be true.

Respondents were also asked which skill they lack or need to improve most to be able to start an entrepreneurship (several answers possible). The most popular answers were "communication, leadership and general management skills" ("54.5\%), "development of business ideas" (53.5\%) and "financial management skills" (51.5\%).

Testing of the same hypothesis was done. The results of test can be seen in Table 2.

Tab. 2: Hypothesis test for country group differences when answering question "Which skills you lack or need to improve most to be able to start an entrepreneurship? "

\begin{tabular}{|l|r|r|}
\hline Answer & p-value & Which hypothesis is true \\
\hline 16.1 Development of business ideas & 0.016 & $\mathrm{H} 1$ \\
\hline $\begin{array}{l}\text { 16.2 Assessment of business potential of } \\
\text { business ideas }\end{array}$ & 0.153 & $\mathrm{H} 0$ \\
\hline $\begin{array}{l}16.3 \text { Communication, leadership and } \\
\text { general management skills }\end{array}$ & 0.165 & $\mathrm{H} 0$ \\
\hline $\begin{array}{l}\text { 16.4 Sales and marketing skills } \\
\text { 16.5 Financial management skills }\end{array}$ & 0.479 & $\mathrm{H} 0$ \\
\hline $\begin{array}{l}\text { 16.6 Specific professional skills related to } \\
\text { industry specifics }\end{array}$ & $<.001$ & $\mathrm{H} 1$ \\
\hline
\end{tabular}

Source: KABADA Survey, 2019.

The outcomes illustrated in Table 2 suggest that there is a substantial difference in selfperception of entrepreneurial skills and capabilities between old EU countries' group and new EU countries group students.

The most popular answers (several answers possible) to the question which are the most important factors discouraging to start an entrepreneurship, turned out to be "lack of necessary financial resources" (63.0\%), "lack of experience and business network" (57.6\%), "lack of knowledge and skills" (49.4\%) and "fear of failure" (47.0\%). Again country group difference hypotheses test was done (see Table 3). 
Tab. 3: Hypothesis test for country group differences when answering question "What are the most important factors discouraging to start an entrepreneurship? “

\begin{tabular}{|l|r|r|}
\hline Answer & p-value & Which hypothesis is true \\
\hline 17.1 Fear of failure & 0.82 & $\mathrm{H}_{0}$ \\
\hline 17.2 Stress, possible impact on my health & 0.112 & $\mathrm{H}_{0}$ \\
\hline 17.3 Lack of knowledge and skills & 0.032 & $\mathrm{H}_{1}$ \\
\hline 17.4 Lack of experience and business network & $<.001$ & $\mathrm{H}_{1}$ \\
\hline 17.5 Lack of necessary financial resources & 0.442 & $\mathrm{H}_{0}$ \\
\hline 17.6 Inappropriate business environment & 0.004 & $\mathrm{H}_{1}$ \\
\hline 17.7 Lack of government support & 0.274 & $\mathrm{H}_{0}$ \\
\hline 17.8 Personal and family preconditions & 0.685 & $\mathrm{H}_{0}$ \\
\hline
\end{tabular}

Source: KABADA Survey, 2019.

The outcomes in Table 3 again suggest that there are three answers where difference between old EU countries' group and new EU countries group students' answers is significant.

Despite the differences between the influencing factors (Tab. 3), students from all 16 countries included in the survey (verification) recognize that the teaching method needs to be improved and modern methods oriented to students related to practice should be used.

Another result (Graph 3) of the study is an attempt to link the skills students lack or need to improve most to be able to start an entrepreneurship (KABADA Survey, 2019) with the methods used in entrepreneurial education (Syed, Rahim and Norita, 2018). 


\section{Graph 3: Link between teaching methods and students' needs}

\begin{tabular}{|c|c|c|}
\hline Method & Strengths & $\begin{array}{l}\text { Con } \\
\text { nect } \\
\text { ions }\end{array}$ \\
\hline Lecture and Exam & $\begin{array}{l}\text { - } \quad \text { Can provide up-to date information } \\
\text { - } \quad \text { Casier to control class } \\
\text { - } \quad \text { Course materials can be easily updated } \\
\text { - } \quad \text { Face-to face interaction }\end{array}$ & 2 \\
\hline Case Study & $\begin{array}{l}\text { - } \quad \text { Illustrate real business context } \\
\text { - } \quad \text { Effective in linking theory and practice } \\
\text { - Improve problem solving and decision making skills } \\
\text { - Interactive educational process } \\
\text { Engages students' minds and enhances their learning more }\end{array}$ & 3 \\
\hline Business Plan & $\begin{array}{l}\text { - } \quad \text { Create business strategy } \\
\text { - } \quad \text { Involves preparation and research } \\
\text { - Involiting skils }\end{array}$ & \\
\hline $\begin{array}{l}\text { Business Simulation } \\
\text { Game }\end{array}$ & $\begin{array}{l}\text { - } \quad \text { Provides hands-on learning experience } \\
\text { - } \quad \text { Effective in developing team-work skills } \\
\text { - }\end{array}$ & \\
\hline Guest Speaker & $\begin{array}{l}\text { - } \quad \text { May provide latest information from the industry } \\
\text { - } \quad \text { Real life examples } \\
\text { - First-hand information }\end{array}$ & \\
\hline $\begin{array}{l}\text { Business Visits and } \\
\text { Field Trip }\end{array}$ & $\begin{array}{l}\text { - } \quad \text { Connect to real world } \\
\text { - } \quad \text { Allow students to observed real business enviro }\end{array}$ & 1 \\
\hline Consultancy Project & $\begin{array}{l}\text { - Develops research skills } \\
\text { - Lead to contact with business community }\end{array}$ & \\
\hline $\begin{array}{l}\text { Problem-based } \\
\text { Learning }\end{array}$ & $\begin{array}{l}\text { - } \quad \text { Develops problem-solving skills } \\
\text { - } \quad \text { Put knowledge into practice } \\
\text { - } \quad \text { Madents may work independently } \\
\end{array}$ & \\
\hline Counselling/Mentoring & $\begin{array}{ll}- & \text { Provides hands-on guidance } \\
\text { - } & \text { Focus discussion }\end{array}$ & 1 \\
\hline $\begin{array}{l}\text { Practical Training and } \\
\text { Working with } \\
\text { Entrepreneur }\end{array}$ & $\begin{array}{l}\text { - Lead to direct contact with business peopl } \\
\text { - Improves communication skills } \\
\text { - } \quad \text { Indect observation of business actiyities } \\
\end{array}$ & 4 \\
\hline
\end{tabular}

\begin{tabular}{|c|c|}
\hline $\begin{array}{l}\text { 16. Which skills you lack or } \\
\text { need to improve most to be } \\
\text { able to start an } \\
\text { entrepreneurship? (choose } \\
\text { three the most important) }\end{array}$ & $\begin{array}{l}\text { KABADA } \\
\text { Survey, } \\
\text { Result, } \\
\text { Significance }\end{array}$ \\
\hline $\begin{array}{ll}\text { - } & \begin{array}{l}\text { Development of business } \\
\text { ideas }\end{array} \\
\end{array}$ & Moderate \\
\hline $\begin{array}{ll} & \text { Assessment of business } \\
& \text { potential of business ideas }\end{array}$ & High \\
\hline $\begin{array}{l}\text { Communication, } \\
\text { leadership and general } \\
\text { management skills }\end{array}$ & High \\
\hline Sales and marketing skills & Moderate \\
\hline $\begin{array}{ll} & \begin{array}{l}\text { Financial management } \\
\text { skills }\end{array} \\
\end{array}$ & High \\
\hline $\begin{array}{ll} & \text { Specific professional skills } \\
\text { related to industry } \\
\text { specifics }\end{array}$ & Moderate \\
\hline
\end{tabular}

Source: KABADA Survey, 2019 and Syed, Rahim and Norita, 2018. 
Using the method of visual analysis (Drieger, 2013) authors conclude that the most intense connections of the students' needs with high significance are with the three teaching methods: "Practical Training and Working with Entrepreneur", "Problem-based Learning "and "Case study"(Graph 3).

\section{Discussion}

Summing up the results of the research: there are low entrepreneurial intensions and growing doubts and fears about business potential in Europe in general. However, significant part of students in European Union wants to establish their own companies and even growingly perceive opportunities. This leads to the authors' belief that innovative digital tool in checking the business idea potential and consulting using multidisciplinary experiences of partners would allow to exploit entrepreneurial potential in the EU that is currently suppressed by fear of failure and deficit of some capabilities.

Students learn better when they are provided with the proper training and have the correct assistance over the time (Min, 2005). Real-world business cases are other possible way to introduce entrepreneurship and help students to develop both creative and feasible solutions. They enable students to focus on real projects, interact with real people and work on real business issues (Bordean, Sonea, 2018). By doing so, students are enabled to develop their creativity and ingenuity, in turn leading to an increased predisposition towards entrepreneurship.

According to Federico Cosenz and Guido Noto (Cosenz, Noto, 2018) entrepreneurial learning is a critical process in realizing the success or failure of a new business venture, as it implies that would-be entrepreneurs acquire those strategic management competencies required to start and manage a new business. Actually, statistics on new businesses failure rate reveal that the main reasons for failure are related to a lack of entrepreneurial competencies of start-uppers.

Lefebvre (2017) conducted several studies dealing with business survival or development issues and came to conclusion that is important for students to keep in touch with entrepreneurs long after the case studies to prolong the brainstorming exercise. 
Neck and Greene (2011) identified the methods that must be applied in order to promote entrepreneurship at the university. They established that the following methods help achieve better results and contribute to successful entrepreneurship education: a portfolio of practice-based pedagogies, including starting businesses as part of the coursework, serious business games and simulations, design-based thinking and reflective practice.

Another student-centred and multidisciplinary method to teaching entrepreneurship is automatic digital system for assessment of business ideas. The system should assess the commercial viability and competitiveness of business idea, assess innovativeness and creativity of business idea, analyze the relevant personal characteristics and preconditions of business idea owner, that will be done automatically or semi-automatically.

The authors argue that higher education institutions will have to use new student-centered teaching methods in entrepreneurship education to stay competitive and to satisfy needs of economy and students in the European Union by the use of emerging opportunities created by artificial intelligence and robotics in digital era.

\section{Conclusions}

The authors believe that despite the low entrepreneurial intensions and growing doubts and fears about business potential in Europe in general the survey shown that significant part of students in European Union have high entrepreneurial intensions and even growingly perceive opportunities in business.

An emerging conclusion of the paper is that although traditional techniques such as lecturing, tutorial and the case study seem to have been commonly used in delivering entrepreneurship subject, no single teaching method appears to be adequate to achieve the objectives of the courses. There has to be a link, relationship between students' desires and needs and methods to fulfil them, as well as combination of theory and practice in order to contribute students' intention to start their own entrepreneurship. Therefore, teaching entrepreneurship should consider the contextual factors and, based on this, combine a number of teaching 
methods in order to provide students with wide range of required skills and an up-to-date knowledge of the entrepreneurial process.

The development of new study programs stimulating entrepreneurship, the involvement of students and lecturers in activities such as businessplan competitions, entrepreneurship clubs and the practical training undertaken in existing start-ups and other enterprises is very important to make entrepreneurship studies more interactive and practical.

To stimulate entrepreneurial intentions among students, creativity training should be included in business educational programs and special cases from real life should be studied as a means do it. Real-world business cases are other possible way to introduce entrepreneurship and help students to develop both creative and feasible solutions. They enable students to focus on real projects, interact with real people and work on real business issues

It is also necessary to develop practical tools like automatic digital system with data mining possibilities for assessment of business ideas of new entrepreneurs and to include such practices in course syllabus, thus offering better education practices.

As a result of the study, the most suitable methods to fulfill students' needs are practical training, working with entrepreneur to keep in touch with entrepreneurs and problem-based learning.

\section{Acknowledgements}

The research was carried out within the framework of the BA School of Business and Finance internal research grant "Application of Modern Teaching Methods in Business Studies in Higher Education". 


\section{References}

AHMAD, N., and SEYMOUR, R., 2008. Defining entrepreneurial activity: definitions supporting frameworks for data collection. OECD Statics working papers, 1.

Available http://www.oecd.org/officialdocuments/publicdisplaydocumentpdf/?doclang uage $=$ en $\&$ cote $=$ std $/$ doc

AMABILE, T. M., 1997. Entrepreneurial creativity through motivational synergy, Journal of Creative Behavior 31. 1, 18-26., https://onlinelibrary.wiley.com/doi/pdf/10.1002/j.21626057.1997.tb00778.x

AUDRETSCH, D. B., 2014. From the entrepreneurial university to the university for the entrepreneurial society, Journal of Technology Transfer. 39(3), 313-321. https://doi.org/10.1007/s10961-012-9288-1

BADRI, R., and HACHICHA, N., 2019. Entrepreneurship education and its impact on students' intention to start up: A sample case study of students from two Tunisian universities. The International Journal of Management Education. (17),182-190.

BARROSO, F., 2012. Factores y razones para desarrollar la creatividad en las empresses [Factors and reasons for developing creativity in enterprises. A study in the Southeastof Mexico] Revista de Ciencias Sociales. 18(3), 509-516.

BARROSO, F., 2017. Motivation for increasing creativity, innovation and entrepreneurship. An experience from the classroom to business firms. Journal of Innovation Management. 5(3), 55-74

BAUBONIENĖ, Ž., HO HAHN, K., PUKSAS, A., and MALINAUSKIENĖ, E., 2018. Factors influencing student entrepreneurship intentions: the case of Lithuanian and South Korean universities. Entrepreneurship and Sustainability Issues. 6(2), 854-871.

BONACCORSI, A., COLOMBO, M. G., GUERINI, M. and ROSSI-LAMASTRA, C., 2013. University specialization and new firm creation across industries, Small Business Economics. 41(4), 837-863. https://doi.org/10.1007/s11187-013-9509-5

BORDEAN, O. N., and SONEA, A., 2018. Student satisfaction and perceived skills: any link to employability? Entrepreneurship and Sustainability Issues. 6(1), 356370. https://doi.org/10.9770/jesi.2018.6.1(22)

BOSMA, N. and KELLEY, D., 2018. Global Entrepreneurship Monitor, 2018/2019 Global Report. Santiago: Gráfica Andes, Available https://www.gemconsortium.org/report/gem-2018-2019-global-report

CEQUEA, M.; RODRÍGUEZ, C. and NÚÑEZ, M., 2011. Diseño de un instrumento para evaluarla productividad laboral en empresas del sector eléctrico venezolano [Instrument Design for Evaluating Labor Productivity in the 
Venezuelan Electrical Sector Enterprises]. Proceedings of the XV International Conference on Industrial Engineering and Industrial Management.

COSENZ, F. and NOTO, G., 2018. Fostering entrepreneurial learning processes through Dynamic Start-up business model simulators. The International Journal of Management Education (16), 468-482.

CHIEF SCIENTIST. 2019. Retrieved from Australia`s Chief Scientist: Available https://www.chiefscientist.gov.au/2015/10/new-report-boosting-highimpact-entrepreneurship-in-australia

CLARYSSE, B. and MORAY, N., 2004. A process study of entrepreneurial team formation: the case of a research-based spin-off, Journal of Business Venturing, 19(1): 55-79. https://doi.org/10.1016/S0883-9026(02)00113-1

DEALE, C. S., 2016. Entrepreneurship education in hospitality and tourism: insights from entrepreneurs. Journal of Teaching in Travel \& Tourism, 16(1), 2039.

DE LA TORRE, S., 1997. Creatividad y formación: identificación, diseño y evaluación[Creativity and formation: identification, design and evaluation]. México: Trillas.

DRUCKER, P. F., 2002. The Discipline of Innovation. Harvard Business Review. Retrieved on February 9, 2015, from https://hbr.org/2002/08/the-disciplineofinnovation/ar/1

DRIEGER, P., 2013. Semantic Network Analysis as a Method for Visual Text Analytics. Procedia - Social and Behavioral Sciences. 79, 4-17.

ENTREPRENEURIAL BEHAVIOR AND ATTITUDES., 2019. Retrieved from Global Entrepreneurship Monitor: https://www.gemconsortium.org/data

FELDMAN, C. \& BOLINO, C., 2000. Career Patterns of the Self-employed: CareerMotivations and Career Outcomes. Journal of Small Business Management. 19(38),53-67.

FINANSES. 2019. Available Latvijas Investīciju un attīstības aǵentūra: http://www.liaa.gov.lv/lv/biznesa-abc/finanses

GLOBAL ENTREPRENEURSHIP RESEARCH ASSOCIATION ENTREPRENEURIAL BEHAVIOR AND ATTITUDES. 2019. Retrieved from Global Entrepreneurship Monitor: https://www.gemconsortium.org/data

GUPTA, P., 2012. The Innovation Solution. Making Innovation More Pervasive, Predictable and Profitable. U.S.A.: Accel per Consulting.

HOOSHANGI, S., ARASTI, M. R., HOUNSHELL, D. A., \& SAHEBZAMANI, S., 2012. Evolutionary learning methodology: A case study of R\&D strategy development. Technological Forecasting \& Social Change. (80), 956-976.

JONES, C., \& ENGLISH, J., 2004. A contemporary approach to entrepreneurship education. Education + Training. 46, 416-423. 
KABADA SURVEY. 2019. Retrieved from KABADA: $h t t p s: / / k a b a d a . e u /$

KATZ, J., 1994. Modeling Entrepreneurial Career Progressions: concepts and considerations. Entrepreneurship: Theory and Practice. 2(19), 23-24.

KIRZNER, I. M., 1973. Competition and Entrepreneurship. Chicago: University of Chicago Press

KNIGHT, F., H., 1921. Risk, Uncertainty, and Profit. Boston: Houghton Mifflin, 1921

KRUMINA, M., 2017. Theoretical aspects of Entrepreneurship. 75th Conference Human resources and social policy. Riga: Latvian University.

LEEUW, A. D., VALOIS, P., AJZEN, I. and SCHMIDT, P., 2015. Using the theory of planned behavior to identify key beliefs underlying pro-environmental behavior in high-school students: Implications for educational interventions. Journal of Environmental Psychology. 42, 128-138.

LEFEBVRE, Q., 2018, “Inspiring Entrepreneurship through Creative Thinking” in The Transforming Power of the Entrepreneurship and Innovation Ecosystem: Lessons Learned, Social Sciences. 131-137. DOI 10.18502/kss.v3i10.2890

MARESCH, D., HARMS, R., KAILER, N. and WIMMER-WURM, B., 2016. The impact of entrepreneurship education on the entrepreneurial intention of students in science and engineering versus business studies university programs. Technological Forecasting and Social Change. 104, 172-179.

MIN, HUI-TZU., 2005. Training students to become successful peer reviewers. System, 33,293-308. Retrieved from http://epi.sc.edu/ar/AS_4_files/Min\%202005.pdf

NECK, H. M. and GREENE, P. G., 2011. Entrepreneurship Education: Known Worlds and New Frontiers, Journal of Small Business Management. 49(1): 5570.https://doi.org/10.1111/j.1540-627X.2010.00314.x

QUIJANO, W., 2006. Dirección de recursos humanos y consultoría en las organizaciones[Human Resources Management and Consulting in Organizations]. Barcelona: Icaria Editorial, S. A.

ROBINSON, K., 2006. Do schools kill creativity? [Film] Available http://ed.ted.com/on/KA5cHhm8

SAGIE, A. and ELIZUR, D., 1999. Achievement motive and entrepreneurial orientation: A structural analysis. Journal of Organizational Behavior. 20, 375387.

SALINAS, D. and BARROSO, F., 2016. Eficacia de un programa de incremento de la motivaciónpara emprender y la productividad de trabajadores a un año de haberse implementado [Efficacy of a program for increasing motivation for entrepreneurship and employees' productivity one year after it was implemented]. Proceedings of the IAnahuac Mayab International Research Congress in Administrative Science(ICAAM). June 1st- 3rd. 
SALINAS, D., 2014. Competencias emprendedoras, motivación para emprender yproductividad. Un estudio en el sureste de México [Entrepreneurship competencies,motivation for entrepreneurship and productivity. A study in the Southeast of Mexico] (Unpublished doctoral dissertation). Anahuac Mayab University, Merida Yucatan Mexico.

SCHUMPETER, J.A., 1943, Capitalism in the postwar world, in S.E. HARRIS (ed.), Postwar Economic Problems, in Essays

SYED, A. Z., ABDUL, A. R. and NORITA, A., 2018. An evaluation of teaching methods of entrepreneurship in hospitality and tourism programs. The International Journal of Management Education. (16), 14-25.

VARLEY, M., HARDY, J. and SEWELL, P. J., 2010. A Developing Joint Educational Framework for Incorporating Employability. International Conference on Engineering Education ICEE-2010. Gliwice.

WARD, T. B., 2004. Cognition, creativity, and entrepreneurship. Journal of Business Journal of Business Venturing. 19(2), 173-188, DOI: 10.1016/S08839026(03)00005-3

\section{Contact address of the author(s):}

Prof. Inese Mavlutova, Dr.sc. administer., Financial Management Department, BA School of Business and Finance, Kr. Valdemara str.161, LV-1013, Riga, Latvia, e-mail: inese.mavlutova@ba.lv

Lect. Māris Krastiņš, Ph.D. stud, Financial Management Department, BA School of Business and Finance, Kr. Valdemara str.161, LV-1013, Riga, Latvia, e-mail: maris.krastins@ba.lv

Lect. Janis Hermanis, Mg.Oec, Finansial Mananagement Department, BA School of Business and Finance, Kr. Valdemara str.161, LV-1013, Riga, Latvia, e-mail: janis.hermanis@ba.lv

Doc. Kristaps Lešinskis, Ph.D. cand, Business Mananagement Department, BA School of Business and Finance, Kr. Valdemara str.161, LV-1013, Riga, Latvia, e-mail: Kristaps.lesinskis@ba.lv

https://doi.org/10.36708/Littera_Scripta2019/2/5 